\title{
Online education and best practices for the development of a distance education program
}

\author{
Andrey Koptelov ${ }^{1 *}$ and Stephen Turner ${ }^{2}$ \\ ${ }^{1}$ Sam Houston State University, Center for International Education, School of Teaching and Learning, \\ Huntsville, Texas, USA \\ ${ }^{2}$ Sam Houston State University, SHSU Online, Huntsville, Texas, USA
}

\begin{abstract}
This article discusses the benefits and challenges of online teaching and learning and details the process for creating a distance education program from the formation of a development team through the creation, implementation and evaluation of courses. It explores current networking technologies and pedagogical approaches that are combined to create a student experience that is satisfying for the current generation of students. The demand for online learning has rapidly increased over the years, especially with the recent COVID-19 situation around the world. Schools transitioned to online teaching and learning. Teachers adapted to the changes and with the help of technology, created collaborative and engaging online experiences. These experiences will be memorable for students. New skills were learned along the way such as organization, time management, communication, etc. These skills can help students and prepare them for their future. Many studies have focused on the topic of teaching and learning online. This study is aimed to target parents, students, and teachers who are looking into furthering or completing their education online. With the recent events in the world happening with COVID-19, children and teachers had to resort to continue their education online. Many families and teachers struggled with technology while others adapted to the situation quickly. To be prepared for any situation we must inform ourselves about how teaching and learning online happens and how to be successful.
\end{abstract}

Keywords: online learning; distance education; technology; higher education.

\section{Introduction}

Online learning challenges in recent years become one of the most relevant topics in the field of education [1-12].

According to the University of the Potomac article [13] on Online Learning VS Traditional Learning, "Online learning is known as the education that takes place over the Internet" (University of the Potomac). This leads to an open door for all students to learn. Teaching and learning online is also defined as an "electronic means of distributing and engaging with learning - typically via the related electronic media services" [14, p. 1].

\footnotetext{
*Corresponding author: axk022@shsu.edu
} 
Teaching online has grown and evolved in so many ways. Dr. Chi-Sing Li did research on online courses and his findings say that there was a shift in education to go from face-toface classes to online courses that was due to convenience for students, financial reasons for colleges, and flexibility [15]. Chi-Sing writes, "Furthermore, it serves the needs of students from various backgrounds and age ranges" $[15, \mathrm{p}$. 4]. Teachers upload assignments online where students can automatically work and submit the assignment in one sitting. Teachers can easily find useful links to help students learn and better understand a topic. Teachers can also use video to film themselves teaching or to teach a class by connecting with them through video chat. With the use of technology, teaching and learning online becomes possible "but it does not change the fundamental processes of human learning" [14, p. 6].

Students may benefit from online learning because they can work at their own pace. It also increases their responsibilities and they can build skills that can help them in the future. However, it is necessary to note that students who struggle in in-person classes tend to struggle even more online. Kareem Farah [16] gives four major tips for teaching online [16]:

1. Keep it simple (do not over complicate).

2. Establish one LMS (learning management system).

3. Prioritize what is most important.

4. Have individual touchpoints for students.

\section{Methods}

Our study analyzes the practice of online learning in United States over the past ten years. We have focused on the following aspects of online learning: student success with online learning, engagement and classroom environment online, E-learning and E-teaching, best practices for the development of a new distance education program, benefits of distance/online education.

\section{Results}

\subsection{Student Success with Online Learning}

How effective is online learning and do students really benefit from it? To explain this, we found articles that have studies on online learning and suggest strategies for student success. With online learning it is important to consider that "most online learners have the responsibilities of children and full-time jobs, responsibilities that make it difficult to manage online learning with their already full lives" [17, p. 5]. One strategy that helps students succeed in online learning is collaborative learning experiences online. Activities that include collaborative learning help students feel connected with each other. It helps students "enhance critical thinking" through "shared reflections, and helpful feedback among peers within the relatively safe context of anonymity" [18, p. 695]. D. Kumar [19] explains that online learning method can be highly effective and efficient for those students who are matured, self-disciplined, motivated and have a high degree of time-management skills, but it is an inappropriate learning environment for the learners who are dependent and unmatured. Young students who lack time-management skills and motivation will not thrive in an online only learning environment. The skills necessary to become a successful online learner must first be learned within the classroom. Like Kumar's [19] online article, the article titled Strengths and Weaknesses of Online Learning describes the benefits of online learning, giving students the flexibility to complete their assignments on their 
schedule, which gives students a sense of ownership and control over their own learning habits.

However, this freedom places a greater responsibility on the student. The student must be well organized with an above average degree of management skills [20]. For this reason, online learning is not appropriate for younger students who are in elementary or middle school. Online learning can be a powerful tool in the appropriate context. In agreement, according to recent studies, students who participated in blended learning courses performed better than traditional face-to-face. This outcome proves that technology and online learning are beneficial only when used in appropriate context. To help students succeed and provide a wonderful online learning experience, teachers also need to create a positive online classroom environment.

\subsection{Engagement and Classroom Environment Online}

In order to create engagement and a positive online classroom environment a teacher has to know their students' demographics. When students feel supported by a teacher or professor who they have not met face to face, they will have a positive attitude towards learning. A positive environment online affects attitude and self-efficacy and may be considered as one of the factors that shape learner's motivation, interest and performance in virtual learning environments Many still wonder how to create an engaging environment when it is online. As for teachers, once we gather data of our students' demographics we have to learn how to use that data to help us support our students. Hannon \& D'Netto [21] found that, "cultural differences do have an impact on participant satisfaction with organizational and technological issues, with local respondents indicating significantly more positive perception than international respondents" (p.1). This information helps us raise awareness to students and families who want to do online learning but may not have any support.

\subsection{Higher Ed E-learning and E-teaching}

With technology at our fingertips it is easier to access education right out of high school.

It may be challenging but online education helps students who may already have families or other responsibilities to take care of. According to Ronsisvalle \& Watkins [22], "as many states respond to student populations that are growing faster than campus facilities can be built, online learning (also known as distance education or e-learning) has been described as "the 'next wave' in technology-based K-12 education". With online education demands growing it is important for educators to find different and engaging ways to deliver content.

University of Illinois [20] listed that online students should be open-minded, organized, have the ability to communicate well in writing, self- motivated and disciplined, not afraid to speak up, able to commit time, able to meet the minimum requirements, have ability to critically think, have access to computers and internet, and believe in online courses. This all makes sense as online learning is a process and students sometimes need to be able to find the answers to their own questions and be self-disciplined to commit the time required. Having students with these qualities can make a difference between successful online teaching and learning, and not successful.

\section{Discussion. Benefits of Distance/Online Education}

For institutions that desire to extend their course offerings to students beyond the immediate geographic region of the institution, distance education courses are an increasingly viable option. 
Distance education is increasingly being chosen as a method of course delivery because it is accessible to a wider range of people than traditional courses. In regard to distance education, Lei and Gupta [23] believe that "the most significant online technological development is the way that the former constraint of time and space has largely been removed by networking capabilities" (p. 617). Previous generations of learners were confined to classrooms for synchronous sessions set by their instructors. For many learners, especially those who sought to take part in specialized programs that were not readily available locally, this was a major deterrent that prevented them from participating. Now however, learners can choose to engage in distance education programs that easily fit their schedules and satisfy their specific needs.

Similarly, faculty members and the institutions they represent benefit from distance education. Tabata and Johnsrud [24] explored faculty opinions about distance education and found that many of the previous perceptions are no longer issues. Many faculty members expressed a belief that courses are difficult to design and implement and that they take more time than traditional courses. Even though this may be the case in some instances, the increased reliance on instructional designers has alleviated these concerns and instructors are finding that they can enjoy many of the same scheduling and geographical freedoms as their students.

Additionally, distance education has a variety of indirect benefits that should not be overlooked. Learners who take part in distance education courses are exposed to technology that they may not otherwise be able to use. They learn how to communicate globally, a skill that is increasingly beneficial in professional settings. By working in an asynchronous environment, they learn personal responsibility and how to schedule their time.

\section{Conclusion}

Looking back at the original question: "Is online teaching effective" We would have to say there are too many factors to be a flat "yes" or "no". Teachers need to be prepared forwards and backwards on their lessons and commit to a lot of time developing the craft of online education. Students need to be mature enough, motivated, well organized, and disciplined to be successful online. Since they aren't in a classroom with a teacher there keeping them on track it becomes up to their internal motivation. We think the better question is, "Can online teaching be effective?" With this question the answer would be yes, absolutely. Regardless of the subject matter of the program, distance education and online learning can be an option when a school or department's goal is to reach a broader base of students than they would using traditional methods. By working collaboratively and following proven pedagogical guidelines, teachers together with program development teams can create student-focused courses that meet the needs of today's generation of learners.

\section{References}

1. N. Abdelrahman, B. Irby, Hybrid Learning. Blended Learning: Concepts, Methodologies, Tools, and Applications (IGI Global, Hershey, 2017). https://doi.org/ 10.4018/978-1-5225-0783-3.ch001

2. G. Chen, Pros and Cons of an Online Education: Is it Right for You (2018). Accessed on: December 5, 2020. [Online]. Available:

https://www.communitycollegereview.com/blog/pros-and-cons-of-an-onlineeducation-is-it-right-for-you 
3. J.A. Crawford, K. Butler-Henderson, J. Rudolph, B. Malkawi, M. Glowatz, R. Burton, P.A. Magni, S. Lam, Journal of Applied Learning \& Teaching, 3(1), 1-20 (2020). https://doi.org/10.37074/jalt.2020.3.1.7

4. D.Z. Hodges, Dean and Provost, 21(12), 3-3 (2020). https://doi.org/10.1002/dap.30754

5. K.J. Kim, G. Kim, Korean Journal of Medical Education, 35(3), 205-214 (2019). https://doi.org/10.3946/kjme.2019.131

6. V. Narayan, J. Herrington, T. Cochrane, Australasian Journal of Educational Technology, 35(3), 86-101 (2018). https://doi.org/10.14742/ajet.3941

7. J. Parker, Journal of Educational Multimedia and Hypermedia, 26(4), 343-356 (2017)

8. Y.H. Pu, T.T. Wu, P.S. Chiu, Y.M. Huang, British Journal of Education Technology, 47, 494-509 (2016). https://doi.org/10.1111/bjet.12443

9. T. Reiners, L.C. Wood, M. Teräs, H. Teräs, S. Gregory, V. Chang, M. Steurer, T. McDonald, A. Fardinpour, Self-guided Exploration of Virtual Learning Spaces, in Authentic Virtual World Education (Springer, New-York, 2018). https://doi.org/10.1007/978-981-10-6382-4_5

10. H. Teräs, U. Kartoglu, International Review of Research in Open and Distance Learning, 18(7), 190-212 (2017). https://doi.org/10.19173/irrodl.v18i7.2923

11. J. Traxler, Research in Learning Technology, 24(24), 1-18 (2016). http://doi.org/10.3402/rlt.v24.31372

12. M. Zheng, L. Ferreira, Journal of Dental Education (to be published) (2020). https://doi.org/10.1002/jdd.12296

13. University of the Potomac, Online Classes vs. Traditional Classes - A Learning Comparison (n.d.). Accessed on: December 16, 2020. [Online]. Available: https://potomac.edu/learning/online- learning-vs-traditional-learning/

14. J. Stephenson, Res High Educ 49, 625 (2018). https://doi.org/10.1007/s11162-0089094-7

15. C. Li, B. Irby, College Student Journal, 42(2), 449-458 (2008)

16. K. Farah, Tips for Teacher Shifting to Teaching Online (2020). Accessed on: December 16, 2020. [Online]. Available: https://www.edutopia.org/article/4-tipssupporting-learning-home

17. T. Stavredes, Effective Online Teaching: Foundations and Strategies for Student Success (John Wiley \& Sons, Hoboken, 2011)

18. A.W. Young, V. Bruce, British Journal of Psychology, 102(4), 695-974 (2011). https://doi.org/10.1111/j.2044-8295.2011.02045.x

19. D. Kumar, Pros and Cons of Online Education (2015). Accessed on: December 16, 2020. [Online]. Available: https://www.ies.ncsu.edu/resources/white-papers/pros-andcons-of-online-education/

20. University of Illinois Springfield, Strengths and Weaknesses of Online Learning - ION Professional eLearning Programs (2020). Accessed on: December 16, 2020. [Online]. Available: https://www.uis.edu/ion/resources/tutorials/online-educationoverview/strengths-and-weaknesses/

21. J. Hannon, B. D’Netto, International Journal of Educational Management, 21(5), 418 432 (2007). https://doi.org/10.1108/09513540710760192

22. T. Ronsisvalle, R. Watkins, Quarterly Review of Distance Education, 6(2), 117-124 (2005)

23. S.A. Lei, R.K. Gupta, Education, 130(4), 616-631 (2010) 
24. L. Tabata, L. Johnsrud, Research in Higher Education, 49(7), 625-646 (2008). https://doi.org/10.1007/s11162-008-9094-7 